\title{
Private Entrepreneurs of Communist Party Members and Corporate Social Responsibility: Evidence from Chinese Private Enterprise Survey
}

\author{
Jianying Li ${ }^{1}$, Weiqi Liu ${ }^{2,3}$, Dongliang Yuan ${ }^{4}$ \\ ${ }^{1}$ School of Economics and Management, Shanxi University, Taiyuan, China \\ ${ }^{2}$ Institute of Management and Decision, Shanxi University, Taiyuan, China \\ ${ }^{3}$ School of Finance, Shanxi University of Finance and Economics, Taiyuan, China \\ ${ }^{4}$ China Academy of Corporate Governance, Nankai University, Tianjin, China \\ Email: 1282812359@qq.com
}

How to cite this paper: Li, J. Y., Liu, W. Q., \& Yuan, D. L. (2020). Private Entrepreneurs of Communist Party Members and Corporate Social Responsibility: Evidence from Chinese Private Enterprise Survey. Theoretical Economics Letters, 10, 635-654. https://doi.org/10.4236/tel.2020.103041

Received: May 11, 2020

Accepted: June 19, 2020

Published: June 22, 2020

Copyright $\odot 2020$ by author(s) and Scientific Research Publishing Inc. This work is licensed under the Creative Commons Attribution International License (CC BY 4.0).

http://creativecommons.org/licenses/by/4.0/

\begin{abstract}
This paper examines whether private entrepreneurs with communist party member status affect corporate social responsibility (CSR) performance of private enterprises. Our empirical result reveals that firms led by private entrepreneurs of communist party members are significantly associated with higher CSR score. The result is robust to confronting several sources of endogeneity, e.g., re-examining the result using propensity score matching (PSM), entropy balancing (EB) and Heckman two-stage estimation, removing the influence of local religious culture. Further, the observed positive relation is particularly sharper for firms with party organization embedding and a good external legal environment. Our findings highlight entrepreneur political affiliation as an important driver of socially responsible corporate decision making.
\end{abstract}

\section{Keywords}

Communist Party Member, Communist Culture, Corporate Social Responsibility, Private Enterprise

\section{Introduction}

Corporate social responsibility (CSR) reflects the extent to which a firm actively engages in responsible business activities and has been considered to be important determinant of firm's sustainability. In China, the number of private enter- 
prises accounts for more than $90 \%$ of the total number of enterprises and they are particularly important to the development of the national economy in terms of employment, tax contributions, and technological innovation ${ }^{1}$. As a result, the topic on the drivers of CSR for private enterprises is becoming interesting to scholars. Some scholars have identified factors that stimulate private enterprises to be involved in CSR activities, including political participant of entrepreneurs (Liang et al., 2010), business owners' social status (Gao et al., 2011), family involvement (Chen and Chen, 2014; Zhu, 2015), industrial associations (Chen et al., 2017) and party organization embedding (Xu et al., 2019). However, the role of the culture behind entrepreneurs' cognition and values is neglected.

China is an ideal laboratory for studying culture and finance. China not only has profound traditional cultures such as Confucianism, Taoism, and Buddhism, but also has communist culture (or red culture) with a rich revolutionary spirit and a heavy historical and cultural connotation. At the macro level, the impact of communist culture on China's macroeconomic development is obvious. The socialist country has become the second largest economy in the world. At the micro level, communist party members are an important carrier of the communist culture, which provides ideas for the study on corporate social responsibility and political culture with Chinese characteristics from a micro perspective. In this paper, we will focus on the question of whether private entrepreneurs of communist party members carrying communist culture have an effect on CSR of private enterprises.

We conjecture that communist party member status is a driver of CSR in the private enterprises. China is a socialist country led by the Communist Party. The purpose of the Communist Party of China is to serve the people wholeheartedly, which has an internal connection with corporate social responsibility behavior that emphasizes responsibility to the society, environment, and employee. Therefore, private entrepreneurs who are members of the Communist Party will also implement the party's purpose. In addition, they are constrained to make more socially responsible decisions due to higher attention and higher moral requirement to communist party members from people. Consequently, we hypothesize that private entrepreneurs of communist party members are positively associated with CSR performance.

We use the data on private enterprise from Chinese Private Enterprise Survey (CPES) to confirm our hypothesis. We use a comprehensive CSR proxy including philanthropy, environmental protection and employee training to capture socially responsible activities of private enterprises. We identify the communist party member status of private entrepreneur based on whether he or she joins the Communist Party of China (CPC). We find a positive and significant association between private entrepreneurs of communist party members and CSR. This result is robust to control for firm-level heterogeneity, entrepreneur-level ${ }^{1}$ See the report on position and role of private enterprises in the national economy from the United Front Work Department of CPC Central Committee. http://www.zytzb.gov.cn/fgjjxw/108015.jhtml 
heterogeneity, industry effect, region effect and year effect. Using propensity score matching (PSM), entropy balancing (EB), Heckman two-stage estimation specifications, and removing the influence of local religious culture, we find that our result and inference is robust to endogeneity concerns. Further, we conduct extended analyses from the internal party organization embedding and external legal environment. We find that the positive relation is stronger for private enterprises with party organization and a good external legal environment.

Our paper makes several contributions. First, it expands the research on the localization of upper echelons theory. We include the communist party member status with Chinese characteristic in the personal characteristics of entrepreneurs. Second, it builds on the growing literation that explores the impact the political culture on financial decision-making (one facet of which is the investment in socially responsible activities). Third, it is a useful supplement to the literature related to the informal system such as culture replacing the formal system.

The paper proceeds as follows. Section 2 reviews previous researches on the characteristics of managers and CSR and develops our hypothesis. Section 3 describes the data and methodology and provides sample descriptives. Section 4 outlines the main results on the effect of private entrepreneurs of communist party members on CSR and discusses the potential endogeneity. Section 5 presents extended analyses on the effect. Section 6 concludes.

\section{Literature Review and Hypothesis Development}

Upper echelons theory creatively developed by Hambrick and Mason (1984) is the theoretical foundation for studying the personal characteristics of managers and corporate social responsibility (CSR). According to this theory, the demographic characteristics of managers will affect their cognitive basis and values, and then affect the decision-making behaviors and strategic choices of enterprises.

Based on upper echelons theory, the relevant study of corporate social responsibility has accumulated rich results. On the one hand, studies at the population physiological characteristics level generally link executives' gender or age with corporate social responsibility. For example, Wang \& Coffey (1992) find that the proportion of female is positively and significantly associated with firms' charitable contributions, an important dimension of CSR. Manner (2010) finds that strong or exemplary corporate social performance, as measured by the strengths categories of KLD's ratings, is positively related to the CEO being female. Similarly, $\mathrm{Xu}$ and $\mathrm{Li}$ (2018) also find that firms with female CEO or higher ratio of female executives are more likely to improve the quality of CSR. These are in line with the views of Galbraith and Stephenson (1993) and Hillman and Dalziel (2003). In essence, both of them believe that female executives keep a watchful eye on ethics, and the human care of female executives is conducive to providing enterprises with more key resources and ability support related to ethics value. Aguinis and Glavas (2012) argue that younger generations are interested in CSR 
because of firm reputation. This is in stark contrast to the evidence in Zhang and Ji (2013) which indicates that the correlation between entrepreneurs' age and the social responsibility information level is significantly positive. However, Oh et al. (2016) do not find the main effect of CEO age on CSR.

On the other hand, studies focus more on the impact of executive's acquired experience on corporate social responsibility. Zhang and Ji (2013) find that the correlation between entrepreneurs' education and the social responsibility information level is significantly positive. Specifically, corporate social performance is better for the CEO having a bachelor's degree in humanities than the CEO having a bachelor's degree in economics (Manner, 2010). Muttakin et al. (2018) find that CEO power using a "power index" that comprises CEO duality, ownership, tenure and family CEO status is negatively associated with CSR disclosures. A recent study by Cronqvist and Yu (2017) examines the female socialization hypothesis in finance by considering how CSR depends on whether a firm's CEO has a daughter. And the empirical results show that when a firm's CEO has a daughter, the corporate social responsibility rating is about $9.1 \%$ higher, compared to a median firm. Similar implication can be found in Yamamura et al. (2019), who show that female teachers affect male but not female pupils' preferences for corporate responsibility later in life. Biological married life is a potent catalyst for inculcating and nourishing prosocial values, preferences and behaviors among family members. Inspired by this, Hegde and Mishra (2019) find that firms led by married CEOs are associated with better CSR. Furthermore, the acquired culture experience can also affect CSR. Based on political culture, Di Giuli and Kostovetsky (2014) provide evidence that firms with Democratic rather than Republican founders score higher on CSR. Based on religious culture, Liao et al. (2019) demonstrate that CEOs' Eastern (Western) religious beliefs have a positive (negative) effect on the incremental eco-innovation of the private enterprises.

Other personal characteristics also have impact on CSR. For example, Tang et al. (2015) find that CEO hubris is negatively related to a firm's socially responsible activities but positively related to its socially irresponsible activities. Mccarthy et al. (2017) find that CEO confidence is negatively related to the level of CSR. Petrenko et al. (2016) find that CEO narcissism has positive effects on levels and profile of organizational CSR. Davidson et al. (2018) find that firms led by materialistic CEOs have lower CSR scores. Yuan et al. (2019) find that firms with more able CEOs, who are better at generating greater output from a given set of input, are associated with more socially responsible activities and fewer socially irresponsible activities.

As Di Giuli and Kostovetsky (2014) and Hutton et al. (2014) highlight, the personal political preferences of managers influence corporate policies. China is a socialist country led by the Communist Party of China (CPC) and has a unique political and cultural background. As the carrier of inheriting communist culture, the communist party members provide convenience for exploring the role 
of communist culture in the corporate social responsibility (Dai et al., 2017). Constitution of the Communist Party of China is the most comprehensive depiction of communist culture, such as closing ties with the people, serving the people wholeheartedly, and working selflessly for the public interests and working to contribute more ${ }^{2}$. Private entrepreneurs who are members of the Communist Party experience party education and training regularly for a long time. In this process, the values of communist culture are deeply embedded in their ideology and then are internalized into the personal values of them. These deep-rooted values enable private entrepreneurs of communist party members to form value judgments about what they can and should do in the daily business activities of the enterprise. Therefore, private entrepreneurs with communist party member status are more able to implement the party's guidelines and policies and guide enterprises to actively fulfill social responsibility.

Reputation restriction may also urge private entrepreneurs of communist party members to undertake corporate social responsibility. The communist party members play an image of paragon and vanguard in the market activity. At the same time, they will also get more social attention and higher expectations from the masses (Gao et al., 2011). Under the dual restriction of personal reputation and corporate reputation, private entrepreneurs of communist party members are supposed to put more emphasis on their commitment and responsibility to stakeholders in the decision-making process, such as the decisions related to philanthropy donation, environmental pollution treatment, and employee training, so as to enhance the social responsibility of enterprises.

Based on the above discussion, private entrepreneurs of communist party members have higher ideological consciousness and stronger sense of identity with communist culture. Moreover, they will incorporate higher ethical standards into strategic decisions of companies under reputational constraints. Therefore, we conjecture that private entrepreneurs' communist party member status may be an important driver of socially responsible corporate decision making. Accordingly, we propose the following hypothesis:

Hypothesis: Private entrepreneurs with communist party member status are positively associated with CSR of private enterprises.

\section{Research Design}

\subsection{Data and Sample}

We obtain data on private enterprise from Chinese Private Enterprise Survey (CPES) conducted by the United Front Work Department of CPC Central ${ }^{2}$ For example, the second article of the Chapter I in Constitution of the Communist Party of China requests that members of the Communist Party of China must serve the people wholeheartedly, dedicate their whole lives to the realization of communism, and be ready to make any personal sacrifices. The third article requests that party member must to adhere to the principle that the interests of the Party and the people stand above everything else, subordinating their personal interests to the interests of the Party and the people, being the first to bear hardships and the last to enjoy comforts, working selflessly for the public interests and working to contribute more. 
Committee, All-China Federation of Industry and Commerce, State Administration for Industry and Commerce of the People's Republic of China, and China Institute of Private Sector. CPES is currently the most concentrated survey on the personal characteristics of private entrepreneurs, especially social and political characteristics. The survey carries out multi-stage stratified random sampling in a certain proportion in provinces, municipalities and autonomous regions of the country to ensure the representativeness of the sample among the private enterprises in the country. Considering the availability of comprehensive corporate social responsibility indicator including philanthropy, environmental protection and employee training, our sample covers the years 2010, 2012 and 2014, which actually correspond to the situation of enterprises in 2009, 2011 and 2013. The sample is further refined by removing observations with missing value, outlier, etc. To mitigate the effect of outliers, we also winsorize some continuous variables at 1st and 99th percentiles. The number of private enterprise in the final sample is 6158 .

It is worth noting that CPES has been used in prior studies to discuss some issues on philanthropy (Liang et al., 2010; Gao et al., 2011; Chen and Chen, 2014), environmental innovation (Liao et al., 2019), or corporate social responsibility (Zhu, 2015; Xu et al., 2019; Chen et al., 2017) of private enterprises. However, our paper is the first to use private enterprise survey data to empirically investigate the impact of private entrepreneurs of communist party members on corporate social responsibility. In addition, compared to previous studies that used only one-year data for analysis, we consider all years in which CSR data is available.

\subsection{Variable Measurement}

Dependent variable. For constructing proxy for corporate social responsibility (CSR), we rely on the following three questions in the questionnaire: 1) cash donated for public welfare undertakings such as poverty alleviation, disaster relief, environmental protection, charity, and cash converted by contribution in kind and engineering labour service; 2) the amount of investment in pollution abatement; 3) expenditure for staff training. We construct three dummy variables based on the answers to the above three questions. CSR_donation is a dummy variable equal to one if the answer to the first question is greater than zero and zero otherwise. CSR_environment is a dummy variable equal to one if the amount of investment in pollution abatement is more than zero and zero otherwise. CSR_employee is a dummy variable equal to one if the expenditure for staff training is more than zero and zero otherwise. The CSR used in the empirical analysis is the sum of these three dummy variables.

Independent variable. Entrepreneurs of communist party members (ECPM) is the main independent variable in our regressions. When private entrepreneurs participated in the questionnaire survey, they were asked to the organizations they joined: the Communist Party of China (CPC), Chinese Democratic Parties, 
or none. ECPM is a dummy variable equal to one if the entrepreneur joined in $\mathrm{CPC}$ and zero otherwise.

Control variables. Following the executive background and CSR literature, we control for a rich set of entrepreneur characteristics and corporate characteristics that are likely to affect CSR of private enterprise. The usual control variables related to entrepreneur characteristics are gender, age, education, compensation, and political connection. Several standard corporate characteristics include firm's age, operation revenue, debt to assets ratio, profitability, and number of staff. In addition, we also control industry, region and year effect. A detailed definition of all the variables used in our analysis is provided in Table 1.

\subsection{Regression Specifications}

To assess how entrepreneurs of communist party members affect CSR of private enterprises, we base our estimations on both ordinary least squares (OLS) and ordered probit (OP). We use the following empirical specification:

$$
\mathrm{CSR}=\alpha+\beta \mathrm{ECPM}+\operatorname{Control}^{T} \cdot \lambda+\delta_{i}+\delta_{r}+\delta_{y}+\varepsilon
$$

Where Control $=$ (Gender, Age Education, Compensation, PI, Establish, Revenue, DTA, Profit, Staff number $)^{T}, \lambda=\left(\lambda_{1}, \cdots \lambda_{10}\right)^{T}$. The dependent variable CSR measures the performance of private enterprises in philanthropy, environment protection, and staff training. Our main independent variable is ECPM, which measures private entrepreneur's communist party member status. The coefficient $\beta$ captures the impact of private entrepreneurs of communist party members on corporate social responsibility. The remaining independent variables, included in Control, capture entrepreneur characteristics and corporate characteristics, as described in Table $1 . \delta_{i}, \delta_{r}$ and $\delta_{y}$ correspond to industry, region and year fixed effects, respectively.

\subsection{Summary Statistics}

Table 2 provides summary statistics of all the variables used in our analysis. In Panel A of Table 2, we report the descriptive statistics based on the number of observations available (i.e., 6158 observations from sample). On average, 39.3\% of private entrepreneurs are communist party members. Comprehensive CSR score is 1.938 , which $74.6 \%$ of private enterprises have cash donation, $42.7 \%$ of private enterprises have investment on pollution abatement, and $76.5 \%$ of private enterprises have expenditure on staff training. The remaining variables in Panel A enter as controls in our regression. There are more male private entrepreneurs ( $86.7 \%$ of the sample) than female private entrepreneurs $(13.3 \%$ of the sample). The average age of private entrepreneurs is 46.43 . And they experience junior or senior high school education on average. $45.8 \%$ of private entrepreneurs are representative of National People's Congress or members of the CPPCC. Firms in our sample are 10.028 years old on average.

Panel B reports the correlation table for variables. There is a significant positive correlation between ECPM and CSR (0.17), suggesting that private entre- 
preneurs with communist party member status contribute to CSR of private enterprises. In order to visually present the corporate differences of the private entrepreneurs of party members and non-party members, we conduct a test on mean and median difference in Panel C. Obviously, whether it is the mean or the median, there is a significant difference in CSR for the private entrepreneurs of party members and non-party members (3.341 and 0.000), indicating that our inference is reasonable.

Table 1. Variable definitions.

\begin{tabular}{|c|c|}
\hline Variables & Definitions \\
\hline \multicolumn{2}{|c|}{ Dependent variable } \\
\hline CSR & $\begin{array}{l}\text { Sum of CSR_donation, CSR_environment and CSR_employee. The minimum } \\
\text { value is zero and the maximum value is three for CSR. CSR_donation is a } \\
\text { dummy variable equal to one if the amount of donation such as public welfare } \\
\text { undertakings, contribution in kind and engineering labour service is greater } \\
\text { than zero and zero otherwise. CSR_environment is a dummy variable equal to } \\
\text { one if the amount of investment in pollution abatement is more than zero and } \\
\text { zero otherwise. CSR_employee is a dummy variable equal to one if the } \\
\text { expenditure for staff training is more than zero and zero otherwise. }\end{array}$ \\
\hline \multicolumn{2}{|c|}{ Independent variable } \\
\hline ECPM & $\begin{array}{l}\text { Indicator that equals one if the entrepreneur is a communist party member and } \\
\text { zero otherwise. }\end{array}$ \\
\hline \multicolumn{2}{|c|}{ Control variables } \\
\hline Gender & Indicator that equals one if the entrepreneur is a man and zero otherwise. \\
\hline Age & $\begin{array}{l}\text { Difference between the year filled in the questionnaire and the year of birth of } \\
\text { the entrepreneur. }\end{array}$ \\
\hline Education & $\begin{array}{l}\text { The value of primary school education or below is zero. The value of junior high } \\
\text { school or senior high school education is one. The value of college education or } \\
\text { above is two. }\end{array}$ \\
\hline Compensation & $\begin{array}{l}\text { Natural logarithm of annual compensation of the entrepreneur (in units of ten } \\
\text { thousand yuan). }\end{array}$ \\
\hline PI & $\begin{array}{l}\text { Political connection. Indicator that equals one if the entrepreneur is } \\
\text { representative of National People's Congress or members of the CPPCC and } \\
\text { zero otherwise. }\end{array}$ \\
\hline Establish & $\begin{array}{l}\text { Difference between the year filled in the questionnaire and the year of } \\
\text { registration of private enterprise. }\end{array}$ \\
\hline Revenue & $\begin{array}{l}\text { Natural logarithm of operation revenue for private enterprise (in units of ten } \\
\text { thousand yuan). }\end{array}$ \\
\hline DTA & The percentage of total debt to total asset. \\
\hline Profit & The percentage of operating profit to operation revenue. \\
\hline Staff number & Natural logarithm of the number of staff for private enterprise. \\
\hline Industry & $\begin{array}{l}\text { Twenty dummy variables were set according to the } 20 \text { industries involved in the } \\
\text { questionnaire. }\end{array}$ \\
\hline Region & Three dummy variables were set according to east, middle and west region. \\
\hline Year & ndar-year dummy. \\
\hline
\end{tabular}

This table describes variable definitions for all the variables constructed based on the 2010, 2012 and 2014 Chinese Private Enterprise Survey (CPES). 
Table 2. Summary statistics.

\begin{tabular}{|c|c|c|c|c|c|c|}
\hline \multicolumn{7}{|c|}{ Panel A: descriptive statistics for key variables } \\
\hline Variable & $\mathrm{N}$ & Mean & Stdev & Min & Median & Max \\
\hline CSR & 6158 & 1.938 & 1.007 & 0.000 & 2.000 & 3.000 \\
\hline $\mathrm{ECPM}$ & 6158 & 0.393 & 0.489 & 0.000 & 0.000 & 1.000 \\
\hline Gender & 6158 & 0.867 & 0.340 & 0.000 & 1.000 & 1.000 \\
\hline Age & 6158 & 46.430 & 8.587 & 16.000 & 46.000 & 93.000 \\
\hline Education & 6158 & 1.582 & 0.641 & 0.000 & 2.000 & 2.000 \\
\hline Compensation & 6158 & 1.075 & 0.423 & 0.301 & 1.000 & 2.301 \\
\hline PI & 6158 & 0.458 & 0.498 & 0.000 & 0.000 & 1.000 \\
\hline Establish & 6158 & 10.028 & 5.346 & 0.000 & 10.000 & 41.000 \\
\hline Revenue & 6158 & 7.391 & 2.353 & 1.792 & 7.601 & 15.727 \\
\hline DTA & 6158 & 26.172 & 26.368 & 0.000 & 20.000 & 89.000 \\
\hline Profit & 6158 & 0.697 & 0.660 & -1.213 & 0.757 & 2.000 \\
\hline Staff number & 6158 & 1.800 & 0.708 & 0.301 & 1.820 & 3.415 \\
\hline
\end{tabular}

Panel B: correlation analysis

\begin{tabular}{|c|c|c|c|c|c|c|c|c|c|c|c|c|}
\hline Variable & 1 & 2 & 3 & 4 & 5 & 6 & 7 & 8 & 9 & 10 & 11 & 12 \\
\hline 1) $\mathrm{CSR}$ & 1 & & & & & & & & & & & \\
\hline 2) $\mathrm{ECPM}$ & 0.17 & 1 & & & & & & & & & & \\
\hline 3) Gender & 0.11 & 0.09 & 1 & & & & & & & & & \\
\hline 4) Age & 0.13 & 0.21 & 0.09 & 1 & & & & & & & & \\
\hline 5) Education & 0.13 & 0.10 & 0.01 & -0.13 & 1 & & & & & & & \\
\hline 6) Compensation & 0.26 & 0.03 & 0.09 & 0.09 & 0.17 & 1 & & & & & & \\
\hline 7) PI & 0.35 & 0.13 & 0.09 & 0.15 & 0.15 & 0.22 & 1 & & & & & \\
\hline 8) Establish & 0.24 & 0.10 & 0.08 & 0.36 & 0.05 & 0.24 & 0.23 & 1 & & & & \\
\hline 9) Revenue & 0.46 & 0.20 & 0.16 & 0.24 & 0.23 & 0.46 & 0.38 & 0.35 & 1 & & & \\
\hline 10) DTA & 0.20 & 0.09 & 0.10 & 0.16 & 0.08 & 0.13 & 0.14 & 0.17 & 0.44 & 1 & & \\
\hline 11) Profit & -0.08 & -0.07 & -0.05 & -0.12 & -0.03 & 0.03 & -0.08 & 0.12 & -0.41 & -0.24 & 1 & \\
\hline 12) Staff number & 0.53 & 0.22 & 0.16 & 0.23 & 0.20 & 0.43 & 0.40 & 0.36 & 0.78 & 0.35 & -0.21 & 1 \\
\hline
\end{tabular}

Panel C: the difference between the private entrepreneurs of party members and non-party members

\begin{tabular}{|c|c|c|c|c|c|c|c|c|}
\hline \multirow[b]{2}{*}{ variable } & \multicolumn{3}{|c|}{$\mathrm{ECPM}=1$} & \multicolumn{3}{|c|}{$\mathrm{ECPM}=0$} & \multirow{2}{*}{$\begin{array}{c}\begin{array}{c}\text { Difference } \\
\text { (mean) }\end{array} \\
\text { T test }\end{array}$} & \multirow{2}{*}{$\begin{array}{c}\begin{array}{c}\text { Difference } \\
\text { (median) }\end{array} \\
Z \text { test }\end{array}$} \\
\hline & $\mathrm{N}$ & Mean & Median & $\mathrm{N}$ & Mean & Median & & \\
\hline CSR & 2423 & 1.988 & 2.000 & 3735 & 1.647 & 2.000 & $0.341^{* * *}$ & $0.000^{* * *}$ \\
\hline Gender & 2423 & 0.905 & 1.000 & 3735 & 0.842 & 1.000 & $0.063^{* * *}$ & \\
\hline Age & 2423 & 48.666 & 49.000 & 3735 & 44.979 & 45.000 & $3.687^{* * *}$ & $4.000^{* * *}$ \\
\hline Education & 2423 & 1.663 & 2.000 & 3735 & 1.530 & 2.000 & $0.133^{* *}$ & \\
\hline Compensation & 2423 & 1.092 & 1.000 & 3735 & 1.065 & 1.000 & $0.026^{* * *}$ & $0.000^{* * *}$ \\
\hline
\end{tabular}


Continued

\begin{tabular}{cccccccccc}
\hline PI & 2423 & 0.537 & 1.000 & 3735 & 0.407 & 0.000 & $0.130^{* * *}$ & $1.000^{* * *}$ \\
Establish & 2423 & 10.674 & 10.000 & 3735 & 9.609 & 9.000 & $1.065^{* * *}$ & $1.000^{* * *}$ \\
Revenue & 2423 & 7.975 & 8.189 & 3735 & 7.010 & 7.222 & $0.964^{* * *}$ & $0.967^{* * *}$ \\
DTA & 2423 & 29.088 & 29.000 & 3735 & 24.281 & 17.000 & $4.807^{* * *}$ & $12.000^{* * *}$ \\
Profit & 2423 & 10.899 & 5.000 & 3735 & 13.392 & 6.477 & $-2.493^{* * *}$ & $-1.477^{* * *}$ \\
Staff number & 2423 & 1.992 & 2.021 & 3735 & 1.676 & 1.699 & $0.316^{* * *}$ & $0.322^{* * *}$ \\
\hline
\end{tabular}

This table reports descriptive statistics, correlation analysis, and difference test of mean and median. CSR is measured as total scores in three categories: CSR_donation, CSR_environment and CSR_employee. CSR_donation is a dummy variable equal to one if the amount of donation such as public welfare undertakings, contribution in kind and engineering labour service is greater than zero and zero otherwise. CSR_environment is a dummy variable equal to one if the amount of investment in pollution abatement is more than zero and zero otherwise. CSR_employee is a dummy variable equal to one if the expenditure for staff training is more than zero and zero otherwise. ECPM is an indicator that equals one if the entrepreneur is a communist party member and zero otherwise. Other variables are as defined in Table 1 . In the correlation analysis, correlations in bold are statistically significant at $p$ value $\leq 0.05$. In difference test, ${ }^{* *},{ }^{* *}$, and ${ }^{*}$ indicate significance at the $1 \%, 5 \%$, and $10 \%$ level, respectively.

\section{Testing Assumption}

\subsection{Baseline Result}

We estimate the effect of private entrepreneurs of communist party members on CSR. The estimated results are presented in Table 3. Column (1) to (3) report OLS regression results and column (4) to (6) show the results of the OP. For comparison, we estimate three specifications: without the control variables, with the control variables on entrepreneur characteristics, with the control variables on corporate characteristics. In these specifications, we find that the coefficient on ECPM is positive and significant at $1 \%$ level, which confirms our hypothesis. Both the OLS and OP results indicate that private entrepreneurs with communist party members status are significantly associated with higher CSR score.

\subsection{Endogeneity Concern}

Our results can be affected by endogeneity concerns resulting from potential selection bias and omitted correlated variables. To mitigate the endogeneity concerns and to check the robustness of our results, we use propensity score matching (PSM), entropy balancing (EB) and Heckman two-stage estimation to estimate Equations (1). We also exclude the impact of local religious culture on CSR of private enterprises.

We divide the sample into treatment group $(\mathrm{ECPM}=1)$ and control group $(\mathrm{ECPM}=0)$ to examine the causal effects of private entrepreneurs of communist party members on CSR for private enterprises. Table 4 reports the results of using one-to-one matching (OM), nearest neighbor matching (NM), caliper matching $(\mathrm{CM})$, kernel matching (KM), radius matching (RM), local linear matching (LM). We find that the average treatment effect on the treated (ATT) is positive and significant at least $10 \%$ level with the exception of using OM. The results suggest that private entrepreneurs of communist party members are better at raising CSR of private enterprises than non-communist party members. That is 
to say, even for OM, the positive relation between private entrepreneurs with communist party member status and CSR is insignificant, we can draw the conclusion that private entrepreneurs of communist party members contribute to the CSR of private enterprises. The results of average treatment effect on the untreated (ATU) also support our finding.

Table 3. Private entrepreneurs of communist party members and CSR.

\begin{tabular}{|c|c|c|c|c|c|c|}
\hline & & OLS & & & OP & \\
\hline & (1) & (2) & (3) & (4) & (5) & (6) \\
\hline ECPM & $\begin{array}{c}0.243^{* * *} \\
(9.77)\end{array}$ & $\begin{array}{c}0.152^{* * *} \\
(6.35)\end{array}$ & $\begin{array}{c}0.072^{* * *} \\
(3.17)\end{array}$ & $\begin{array}{l}0.368^{* * *} \\
(13.08)\end{array}$ & $\begin{array}{c}0.253^{* * *} \\
(8.56)\end{array}$ & $\begin{array}{l}0.101^{* * *} \\
(3.29)\end{array}$ \\
\hline Gender & & $\begin{array}{c}0.103^{* * *} \\
(3.06)\end{array}$ & $\begin{array}{l}0.042 \\
(1.34)\end{array}$ & & $\begin{array}{c}0.191^{* * *} \\
(4.77)\end{array}$ & $\begin{array}{l}0.058 \\
(1.38)\end{array}$ \\
\hline Age & & $\begin{array}{l}0.003^{* *} \\
(2.02)\end{array}$ & $\begin{array}{c}-0.004^{* * *} \\
(-2.87)\end{array}$ & & $\begin{array}{c}0.007^{* * *} \\
(3.97)\end{array}$ & $\begin{array}{c}-0.005^{* * *} \\
(-2.68)\end{array}$ \\
\hline Education & & $\begin{array}{c}0.110^{* * *} \\
(5.98)\end{array}$ & $\begin{array}{l}0.024 \\
(1.34)\end{array}$ & & $\begin{array}{c}0.095^{* * *} \\
(4.19)\end{array}$ & $\begin{array}{l}0.023 \\
(0.97)\end{array}$ \\
\hline Compensation & & $\begin{array}{l}0.351^{* * *} \\
(12.60)\end{array}$ & $\begin{array}{l}0.064^{* *} \\
(2.25)\end{array}$ & & $\begin{array}{l}0.461^{* * *} \\
(13.41)\end{array}$ & $\begin{array}{l}-0.013 \\
(-0.31)\end{array}$ \\
\hline PI & & $\begin{array}{l}0.499^{* * *} \\
(20.88)\end{array}$ & $\begin{array}{l}0.285^{* * *} \\
(12.00)\end{array}$ & & $\begin{array}{l}0.636^{* * *} \\
(22.08)\end{array}$ & $\begin{array}{l}0.349^{* * *} \\
(11.07)\end{array}$ \\
\hline Revenue & & & $\begin{array}{c}0.052^{* * *} \\
(6.33)\end{array}$ & & & $\begin{array}{c}0.109^{* * *} \\
(8.82)\end{array}$ \\
\hline Establish & & & $\begin{array}{c}0.009^{* * *} \\
(3.90)\end{array}$ & & & $\begin{array}{c}0.011^{* * *} \\
(3.60)\end{array}$ \\
\hline DTA & & & $\begin{array}{l}-0.001 \\
(-1.09)\end{array}$ & & & $\begin{array}{l}-0.000 \\
(-0.20)\end{array}$ \\
\hline Profit & & & $\begin{array}{l}0.000 \\
(1.40)\end{array}$ & & & $\begin{array}{c}0.216^{* * *} \\
(8.78)\end{array}$ \\
\hline Staff number & & & $\begin{array}{l}0.418^{* * *} \\
(16.18)\end{array}$ & & & $\begin{array}{l}0.504^{* * *} \\
(13.54)\end{array}$ \\
\hline Industry & Yes & Yes & Yes & Yes & Yes & Yes \\
\hline Region & Yes & Yes & Yes & Yes & Yes & Yes \\
\hline Year & Yes & Yes & Yes & Yes & Yes & Yes \\
\hline $\mathrm{R}^{2}$ & 0.135 & 0.246 & 0.334 & & & \\
\hline Pseudo $\mathrm{R}^{2}$ & & & & 0.010 & 0.069 & 0.152 \\
\hline $\mathrm{N}$ & 6158 & 6158 & 6158 & 6158 & 6158 & 6158 \\
\hline
\end{tabular}

This table reports both OLS and OP regression results of the effect of private entrepreneurs of communist party members on CSR, measured as total scores in three categories: CSR_donation, CSR_environment and CSR_employee. CSR_donation is a dummy variable equal to one if the amount of donation such as public welfare undertakings, contribution in kind and engineering labour service is greater than zero and zero otherwise. CSR_environment is a dummy variable equal to one if the amount of investment in pollution abatement is more than zero and zero otherwise. CSR_employee is a dummy variable equal to one if the expenditure for staff training is more than zero and zero otherwise. Independent variable EPCM is an indicator that equals one if the entrepreneur is a communist party member and zero otherwise. Other variables are as defined in Table 1 . T-statistics are given in parentheses. ${ }^{* *},{ }^{* *}$, and ${ }^{*}$ indicate significance at the $1 \%$, $5 \%$, and $10 \%$ level, respectively. 
Table 4. Propensity score matching (PSM): effect of private entrepreneurs of communist party members on CSR.

\begin{tabular}{ccccccc}
\hline & OM & NM & CM & KM & RM & LM \\
\hline \multirow{2}{*}{ ATT } & 0.037 & $0.060^{*}$ & $0.060^{* *}$ & $0.066^{* * *}$ & $0.065^{* * *}$ & $0.073^{* * *}$ \\
& $(1.02)$ & $(1.89)$ & $(2.05)$ & $(2.76)$ & $(2.73)$ & $(3.40)$ \\
\multirow{2}{*}{ ATU } & $0.087^{* *}$ & $0.092^{* * *}$ & $0.095^{* * *}$ & $0.105^{* * *}$ & $0.098^{* * *}$ & $0.080^{* * *}$ \\
& $(2.23)$ & $(3.16)$ & $(2.87)$ & $(3.78)$ & $(3.67)$ & $(3.24)$ \\
& & & & & & \\
ATE & $0.067^{* *}$ & $0.079^{* * *}$ & $0.081^{* * *}$ & $0.090^{* * *}$ & $0.085^{* * *}$ & $0.077^{* * *}$ \\
& $(2.23)$ & $(3.04)$ & $(3.01)$ & $(3.69)$ & $(3.55)$ & $(3.66)$ \\
\hline
\end{tabular}

This table reports average treatment effect on the treated (ATT), average treatment effect on the untreated (ATU) and average treatment effect (ATE) using six matching methods: one-to-one matching (OM), nearest neighbor matching $(\mathrm{NM})$, caliper matching $(\mathrm{CM})$, kernel matching $(\mathrm{KM})$, radius matching $(\mathrm{RM})$, local linear matching $(\mathrm{LM})$. The treatment and control groups correspond to $\mathrm{ECPM}=1$ and $\mathrm{ECPM}=0$, respectively. Variable definition details are shown in Table 1 . T-statistics are given in parentheses. ${ }^{* *}$, ${ }^{* *}$, and * indicate significance at the $1 \%, 5 \%$, and $10 \%$ level, respectively.

Considering the possible sample selection bias between the treatment group and the control group, we further use the entropy balance (EB) method proposed by Hainmueller (2012) to perform weighted balance processing on the treatment and control group. Entropy balance can ensure that the treatment and control group achieve a balance on the sample characteristics, which will produce smaller coefficient bias and standard error than PSM. Table 5 reports the results from EM analysis. In column (1), we show estimates based on raw data, and do not control for any entrepreneur characteristics or corporate characteristics. The estimated coefficient on ECPM is 0.064 and statistically significant at the $5 \%$ level. In column (2) to (3), we add a set of standard entrepreneur and corporate controls one by one. And the significance level does not attenuate dramatically when we add controls for entrepreneur and corporate characteristics. The estimated coefficients on ECPM are $0.063(t=2.61)$ and $0.070(t=$ $3.05)$, respectively. The evidence reveals a statistically significant and positive relation between entrepreneurs with communist party member status and CSR in Chinese private enterprises.

Another test for sample selection bias is Heckman two-step estimation, in which the first step adopts a probit model to predict the likelihood of private entrepreneurs of communist party members and calculates the predicted inverse Mills ratio (IMR), and the second step estimates the CSR performance using the IMR as a predictor in the model (1). We report the results of using Heckman two-step estimation in Table 6. Column (1) is the result of the first step regression and the dependent variable is ECPM. Column (2) to (4) are the results of the second step regression and the dependent variable is CSR. We add a set of standard entrepreneur controls in column (3) and corporate controls in column (4). Obviously, the coefficients on ECPM are positive and significant at the $1 \%$ level (0.071, 0.078 and 0.074). Significant and negative coefficients on IMR indicate the existence of sample selection bias. Again, this demonstrates that the communist party member status effect we focus on is statistically significant. 
In addition, we also exclude the impact of religious culture on CSR. It is important to emphasize that the communist party members have no religious belief. We only eliminate the influence of the religious culture in the region where the private enterprise is located, which is measured as the natural logarithm of the number of religious places in the region where the private enterprise is located. We report the results of excluding religious culture in Table 7. In column (1) to (5), we include the Buddhism, Taoism, Christian, Muslim, and Catholicism control, respectively. In column (6), we include all of the religion controls simultaneously. Clearly, the coefficients on the ECPM are positive and significant at the $1 \%$ level in all specifications.

In summary, the results in Tables 5-8 are consistent with the main results in Table 3, and hence our overall inference on the effect of private entrepreneurs of communist party members on CSR is robust to concerns about endogeneity.

\section{Further Analyses}

In this section, we test whether our results are more pronounced from the perspective of party organization embedding in the private enterprise and external legal environment. We measure the party organization embedding (Party) according to the presence or absence of party organization in private enterprise. We measure the legal environment (Legal) in the region where the private enterprise is located by using the legal environment index of China's provinces in Wang et al. (2018). We particularly focus on the coefficient on the interaction term between Party (or Legal) and ECPM. Similarly, we perform the OLS and OP regression as in Table 3 and the results are shown in Table 8.

The column (1) and (3) present the OLS and OP regression results on the role of party organization embedding in the relation of private entrepreneurs of communist party members and CSR, respectively. Positive and significant coefficients on $\mathrm{ECPM}^{\star} \mathrm{Party}(0.204$ and 0.307$)$ suggest that the effect of private entrepreneurs of communist party members on CSR is stronger when the party organization exists in the private enterprise. The column (2) and (4) present the OLS and OP regression results on the role of regional legal environment in the relation of private entrepreneurs of communist party members and CSR, respectively. We find significant and positive coefficients on the interaction term $\mathrm{ECPM}^{\star}$ Legal $(0.030$ and 0.042$)$. This shows that the regional legal environment provides a good external environment for private entrepreneurs of communist party members to better fulfill CSR. That is, the effect of private entrepreneurs of communist party members on CSR is stronger with improvement of legal environment in the region where the private enterprise is located.

\section{Conclusion}

Based on the data from Chinese Private Enterprise Survey, this paper empirically investigates the impact of private entrepreneurs of communist party members on CSR. We find that private entrepreneurs with communist party member sta- 
tus have a positive effect on CSR of private enterprises. Our finding is robust to entrepreneur characteristics and corporate characteristics, and doesn't seem to a result of endogeneity problems. Further analyses show that this positive relation is stronger for private enterprises that have a party organization within the enterprise and a good external legal environment. It implies that the communism culture is crucial to shape the spirit of responsibility for individual. Our research is a useful supplement to the literatures on the relationship between political beliefs and corporate social responsibility.

Table 5. Entropy balancing (EB): effect of private entrepreneurs of communist party members on CSR.

\begin{tabular}{|c|c|c|c|}
\hline & (1) & (2) & (3) \\
\hline ECPM & $\begin{array}{c}0.064^{* *} \\
(2.50)\end{array}$ & $\begin{array}{c}0.063^{* * *} \\
(2.61)\end{array}$ & $\begin{array}{c}0.070^{* * *} \\
(3.05)\end{array}$ \\
\hline Gender & & $\begin{array}{c}0.156^{* * *} \\
(3.95)\end{array}$ & $\begin{array}{c}0.089^{* *} \\
(2.37)\end{array}$ \\
\hline Age & & $\begin{array}{l}0.003^{*} \\
(1.77)\end{array}$ & $\begin{array}{l}-0.002 \\
(-1.56)\end{array}$ \\
\hline Education & & $\begin{array}{c}0.098^{* * *} \\
(4.62)\end{array}$ & $\begin{array}{l}0.004 \\
(0.20)\end{array}$ \\
\hline Compensation & & $\begin{array}{c}0.305^{* * *} \\
(9.84)\end{array}$ & $\begin{array}{l}-0.014 \\
(-0.42)\end{array}$ \\
\hline PI & & $\begin{array}{l}0.437^{* * *} \\
(17.16)\end{array}$ & $\begin{array}{c}0.252^{* * *} \\
(9.92)\end{array}$ \\
\hline Establish & & & $\begin{array}{c}0.008^{* * *} \\
(3.20)\end{array}$ \\
\hline Revenue & & & $\begin{array}{c}0.084^{* * *} \\
(8.52)\end{array}$ \\
\hline DTA & & & $\begin{array}{l}0.000 \\
(0.65)\end{array}$ \\
\hline Profit & & & $\begin{array}{c}0.139^{* * *} \\
(7.06)\end{array}$ \\
\hline Staff number & & & $\begin{array}{l}0.329^{* * *} \\
(11.29)\end{array}$ \\
\hline Industry & Yes & Yes & Yes \\
\hline Region & Yes & Yes & Yes \\
\hline Year & Yes & Yes & Yes \\
\hline $\mathrm{R}^{2}$ & 0.101 & 0.194 & 0.288 \\
\hline $\mathrm{N}$ & 6158 & 6158 & 6158 \\
\hline
\end{tabular}

This table reports the regression results of entropy balancing (EB) analysis. CSR is measured as total scores in three categories: CSR_donation, CSR_environment and CSR_employee. CSR_donation is a dummy variable equal to one if the amount of donation such as public welfare undertakings, contribution in kind and engineering labour service is greater than zero and zero otherwise. CSR_environment is a dummy variable equal to one if the amount of investment in pollution abatement is more than zero and zero otherwise. CSR_employee is a dummy variable equal to one if the expenditure for staff training is more than zero and zero otherwise. ECPM is an indicator that equals one if the entrepreneur is a communist party member and zero otherwise. Other variables are as defined in Table 1 . T-statistics are given in parentheses. ${ }^{* * *},{ }^{* *}$, and ${ }^{*}$ indicate significance at the $1 \%, 5 \%$, and $10 \%$ level, respectively. 
Table 6. Heckman two-step estimation: effect of private entrepreneurs of communist party members on CSR.

\begin{tabular}{|c|c|c|c|c|}
\hline & (1) & (2) & (3) & (4) \\
\hline Variable & ECPM & CSR & CSR & CSR \\
\hline ECPM & & $\begin{array}{c}0.071^{* * *} \\
(2.89)\end{array}$ & $\begin{array}{l}0.078^{* * *} \\
(3.40)\end{array}$ & $\begin{array}{c}0.074^{* * *} \\
(3.27)\end{array}$ \\
\hline Gender & $\begin{array}{l}0.185^{* * *} \\
(3.52)\end{array}$ & & $\begin{array}{c}-0.265^{* * *} \\
(-7.64)\end{array}$ & $\begin{array}{c}-0.127^{* *} \\
(-1.99)\end{array}$ \\
\hline Age & $\begin{array}{l}0.030^{* * *} \\
(13.45)\end{array}$ & & $\begin{array}{l}-0.048^{* * *} \\
(-20.77)\end{array}$ & $\begin{array}{c}-0.030^{* * *} \\
(-3.47)\end{array}$ \\
\hline Education & $\begin{array}{l}0.227^{* * *} \\
(7.88)\end{array}$ & & $\begin{array}{c}-0.341^{\star \star *} \\
(-14.05)\end{array}$ & $\begin{array}{c}-0.176^{* * *} \\
(-2.59)\end{array}$ \\
\hline Compensation & $\begin{array}{c}-0.225^{* * *} \\
(-4.95)\end{array}$ & & $\begin{array}{l}0.441^{* * *} \\
(16.61)\end{array}$ & $\begin{array}{c}0.259^{* * *} \\
(3.70)\end{array}$ \\
\hline PI & $\begin{array}{l}0.055 \\
(1.46)\end{array}$ & & $\begin{array}{c}0.223^{* * *} \\
(8.97)\end{array}$ & $\begin{array}{c}0.234^{* * *} \\
(8.09)\end{array}$ \\
\hline Establish & $\begin{array}{l}-0.005 \\
(-1.43)\end{array}$ & & & $\begin{array}{c}0.013^{* * *} \\
(4.89)\end{array}$ \\
\hline Revenue & $\begin{array}{c}0.055^{* * *} \\
(4.19)\end{array}$ & & & $\begin{array}{l}0.002 \\
(0.11)\end{array}$ \\
\hline DTA & $\begin{array}{l}-0.001 \\
(-0.70)\end{array}$ & & & $\begin{array}{l}-0.000 \\
(-0.09)\end{array}$ \\
\hline Profit & $\begin{array}{l}0.000 \\
(0.75)\end{array}$ & & & $\begin{array}{l}0.000 \\
(0.48)\end{array}$ \\
\hline Staff number & $\begin{array}{l}0.188^{* * *} \\
(4.563)\end{array}$ & & & $\begin{array}{c}0.261^{\star * *} \\
(4.53)\end{array}$ \\
\hline IMR & & $\begin{array}{l}-1.127^{* * *} \\
(-25.39)\end{array}$ & $\begin{array}{l}-2.323^{* * *} \\
(-26.71)\end{array}$ & $\begin{array}{c}-1.262^{* * *} \\
(-3.05)\end{array}$ \\
\hline Industry & Yes & Yes & Yes & Yes \\
\hline Region & Yes & Yes & Yes & Yes \\
\hline Year & Yes & Yes & Yes & Yes \\
\hline $\mathrm{R}^{2}$ & & 0.217 & 0.325 & 0.334 \\
\hline $\mathrm{N}$ & 6158 & 6158 & 6158 & 6158 \\
\hline
\end{tabular}

This table reports the regression results of Heckman two-step estimation. Column (1) is the result of the first step regression and the dependent variable is ECPM, measured as an indicator that equals one if the entrepreneur is a communist party member and zero otherwise. Column (2) to (4) are the results of the second step regression and the dependent variable is CSR, measured as total scores in three categories: CSR_donation, CSR_environment and CSR_employee. CSR_donation is a dummy variable equal to one if the amount of donation such as public welfare undertakings, contribution in kind and engineering labour service is greater than zero and zero otherwise. CSR_environment is a dummy variable equal to one if the amount of investment in pollution abatement is more than zero and zero otherwise. CSR_employee is a dummy variable equal to one if the expenditure for staff training is more than zero and zero otherwise. IMR is the inverse Mills ratio, which is a control variable for the second step regression. Other variables are as defined in Table 1. T-statistics are given in parentheses. ${ }^{* *},{ }^{* *}$, and ${ }^{*}$ indicate significance at the $1 \%, 5 \%$, and $10 \%$ level, respectively. 
Table 7. The effect of excluding religious culture.

\begin{tabular}{|c|c|c|c|c|c|c|}
\hline Variable & (1) & (2) & (3) & (4) & (5) & (6) \\
\hline ECPM & $\begin{array}{c}0.071^{* * *} \\
(3.15)\end{array}$ & $\begin{array}{c}0.071^{* * *} \\
(3.13)\end{array}$ & $\begin{array}{l}0.074^{* * *} \\
(3.26)\end{array}$ & $\begin{array}{l}0.072^{* * *} \\
(3.18)\end{array}$ & $\begin{array}{l}0.073^{* * *} \\
(3.24)\end{array}$ & $\begin{array}{c}0.069^{* * *} \\
(3.07)\end{array}$ \\
\hline Gender & $\begin{array}{l}0.041 \\
(1.28)\end{array}$ & $\begin{array}{l}0.043 \\
(1.34)\end{array}$ & $\begin{array}{l}0.045 \\
(1.42)\end{array}$ & $\begin{array}{l}0.047 \\
(1.47)\end{array}$ & $\begin{array}{l}0.045 \\
(1.43)\end{array}$ & $\begin{array}{l}0.043 \\
(1.35)\end{array}$ \\
\hline Age & $\begin{array}{l}-0.003^{* *} \\
(-2.34)\end{array}$ & $\begin{array}{l}-0.003^{* *} \\
(-2.41)\end{array}$ & $\begin{array}{l}-0.003^{* *} \\
(-2.53)\end{array}$ & $\begin{array}{c}-0.004^{* * *} \\
(-2.59)\end{array}$ & $\begin{array}{l}-0.004^{* *} \\
(-2.56)\end{array}$ & $\begin{array}{l}-0.003^{* *} \\
(-2.33)\end{array}$ \\
\hline Education & $\begin{array}{l}0.025 \\
(1.39)\end{array}$ & $\begin{array}{l}0.023 \\
(1.25)\end{array}$ & $\begin{array}{l}0.021 \\
(1.14)\end{array}$ & $\begin{array}{l}0.017 \\
(0.96)\end{array}$ & $\begin{array}{l}0.019 \\
(1.05)\end{array}$ & $\begin{array}{l}0.023 \\
(1.26)\end{array}$ \\
\hline Compensation & $\begin{array}{l}-0.003 \\
(-0.12)\end{array}$ & $\begin{array}{l}-0.003 \\
(-0.11)\end{array}$ & $\begin{array}{l}-0.002 \\
(-0.07)\end{array}$ & $\begin{array}{l}0.002 \\
(0.06)\end{array}$ & $\begin{array}{l}-0.002 \\
(-0.07)\end{array}$ & $\begin{array}{l}0.001 \\
(0.04)\end{array}$ \\
\hline PI & $\begin{array}{l}0.273^{* * *} \\
(11.49)\end{array}$ & $\begin{array}{l}0.275^{* * *} \\
(11.55)\end{array}$ & $\begin{array}{l}0.273^{* * *} \\
(11.45)\end{array}$ & $\begin{array}{l}0.273^{* * *} \\
(11.44)\end{array}$ & $\begin{array}{l}0.275^{* * *} \\
(11.57)\end{array}$ & $\begin{array}{l}0.269^{* * *} \\
(11.26)\end{array}$ \\
\hline Establish & $\begin{array}{c}0.009^{* * *} \\
(3.74)\end{array}$ & $\begin{array}{c}0.008^{* * *} \\
(3.70)\end{array}$ & $\begin{array}{l}0.009^{* * *} \\
(3.74)\end{array}$ & $\begin{array}{l}0.009^{* * *} \\
(3.78)\end{array}$ & $\begin{array}{c}0.008^{* * *} \\
(3.73)\end{array}$ & $\begin{array}{c}0.009^{* * *} \\
(3.88)\end{array}$ \\
\hline Revenue & $\begin{array}{c}0.081^{* * *} \\
(8.84)\end{array}$ & $\begin{array}{c}0.081^{* * *} \\
(8.84)\end{array}$ & $\begin{array}{l}0.081^{* * *} \\
(8.88)\end{array}$ & $\begin{array}{c}0.081^{* * *} \\
(8.88)\end{array}$ & $\begin{array}{c}0.081^{* * *} \\
(8.87)\end{array}$ & $\begin{array}{c}0.081^{* * *} \\
(8.87)\end{array}$ \\
\hline DTA & $\begin{array}{l}-0.000 \\
(-0.05)\end{array}$ & $\begin{array}{l}-0.000 \\
(-0.04)\end{array}$ & $\begin{array}{l}0.000 \\
(0.08)\end{array}$ & $\begin{array}{l}0.000 \\
(0.06)\end{array}$ & $\begin{array}{l}0.000 \\
(0.00)\end{array}$ & $\begin{array}{l}0.000 \\
(0.02)\end{array}$ \\
\hline Profit & $\begin{array}{c}0.158^{* * *} \\
(8.68)\end{array}$ & $\begin{array}{c}0.158^{* * *} \\
(8.66)\end{array}$ & $\begin{array}{l}0.158^{* * *} \\
(8.68)\end{array}$ & $\begin{array}{c}0.157^{* * *} \\
(8.58)\end{array}$ & $\begin{array}{c}0.157^{* * *} \\
(8.59)\end{array}$ & $\begin{array}{c}0.158^{* * *} \\
(8.66)\end{array}$ \\
\hline Staff number & $\begin{array}{l}0.380^{* * *} \\
(14.00)\end{array}$ & $\begin{array}{l}0.379^{* * *} \\
(13.94)\end{array}$ & $\begin{array}{l}0.381^{* * *} \\
(14.04)\end{array}$ & $\begin{array}{l}0.382^{* * *} \\
(14.07)\end{array}$ & $\begin{array}{l}0.382^{* * *} \\
(14.06)\end{array}$ & $\begin{array}{l}0.381^{* * *} \\
(14.01)\end{array}$ \\
\hline Buddhism & $\begin{array}{c}0.024^{* * *} \\
(3.15)\end{array}$ & & & & & $\begin{array}{l}0.027 \\
(1.54)\end{array}$ \\
\hline Taoism & & $\begin{array}{c}0.016^{* * *} \\
(2.74)\end{array}$ & & & & $\begin{array}{l}0.004 \\
(0.30)\end{array}$ \\
\hline Christian & & & $\begin{array}{l}0.054^{* *} \\
(2.56)\end{array}$ & & & $\begin{array}{l}0.017 \\
(0.58)\end{array}$ \\
\hline Muslim & & & & $\begin{array}{l}0.013^{*} \\
(1.66)\end{array}$ & & $\begin{array}{l}0.021^{* *} \\
(2.41)\end{array}$ \\
\hline Catholicism & & & & & $\begin{array}{l}0.002 \\
(0.16)\end{array}$ & $\begin{array}{l}-0.026^{*} \\
(-1.83)\end{array}$ \\
\hline Industry & Yes & Yes & Yes & Yes & Yes & Yes \\
\hline Region & Yes & Yes & Yes & Yes & Yes & Yes \\
\hline Year & Yes & Yes & Yes & Yes & Yes & Yes \\
\hline $\mathrm{R}^{2}$ & 0.343 & 0.342 & 0.342 & 0.342 & 0.342 & 0.344 \\
\hline $\mathrm{N}$ & 6158 & 6158 & 6158 & 6158 & 6158 & 6158 \\
\hline
\end{tabular}

This table reports the regression results of excluding religious culture. Column (1) to (5) control the Buddhism, Taoism, Christian, Muslim, and Catholicism, respectively. Column (6) includes all of the religion controls simultaneously. Buddhism and Taoism are measured as natural logarithm of the number of Buddhism temple and Taoist abbey in the region where the private enterprise is located. Christian, Muslim, and Catholicism are measured as natural logarithm of the number of Christian church, Muslim church, and Catholicism church in the region where the private enterprise is located. The dependent variable CSR is measured as total scores in three categories: CSR_donation, CSR_environment and CSR_employee. CSR_donation is a dummy variable equal to one if the amount of donation such as public welfare undertakings, contribution in kind and engineering labour service is greater than zero and zero otherwise. CSR_environment is a dummy variable equal to one if the amount of investment in pollution abatement is more than zero and zero otherwise. CSR_employee is a dummy variable equal to one if the expenditure for staff training is more than zero and zero otherwise. The independent variable ECPM is measured as an indicator that equals one if the entrepreneur is a communist party member and zero otherwise. Other variables are as defined in Table 1 . T-statistics are given in parentheses. ${ }^{* *},{ }^{* *}$, and ${ }^{*}$ indicate significance at the $1 \%, 5 \%$, and $10 \%$ level, respectively. 
J. Y. Li et al.

Table 8. The role of party organization embedding and regional legal environment.

\begin{tabular}{|c|c|c|c|c|}
\hline & \multicolumn{2}{|c|}{ OLS } & \multicolumn{2}{|c|}{ OP } \\
\hline & (1) & (2) & (3) & (4) \\
\hline ECPM & $\begin{array}{c}0.061^{* * *} \\
(2.62)\end{array}$ & $\begin{array}{l}0.068^{* *} \\
(2.27)\end{array}$ & $\begin{array}{l}0.083^{* * *} \\
(2.64)\end{array}$ & $\begin{array}{l}0.072^{* *} \\
(2.17)\end{array}$ \\
\hline Party & $\begin{array}{l}-0.098 \\
(-1.47)\end{array}$ & & $\begin{array}{l}-0.139 \\
(-1.55)\end{array}$ & \\
\hline $\mathrm{ECPM}^{\star}$ Party & $\begin{array}{l}0.204^{* *} \\
(2.13)\end{array}$ & & $\begin{array}{c}0.307^{* *} \\
(2.33)\end{array}$ & \\
\hline Legal & & $\begin{array}{l}-0.012 \\
(-1.10)\end{array}$ & & $\begin{array}{l}-0.020 \\
(-1.36)\end{array}$ \\
\hline $\mathrm{ECPM}^{\star}$ Legal & & $\begin{array}{l}0.030^{* *} \\
(2.38)\end{array}$ & & $\begin{array}{l}0.042^{* *} \\
(2.45)\end{array}$ \\
\hline Gender & $\begin{array}{l}0.042 \\
(1.35)\end{array}$ & $\begin{array}{l}0.043 \\
(1.37)\end{array}$ & $\begin{array}{l}0.054 \\
(1.28)\end{array}$ & $\begin{array}{l}0.055 \\
(1.30)\end{array}$ \\
\hline Age & $\begin{array}{c}-0.003^{* *} \\
(-2.48)\end{array}$ & $\begin{array}{c}-0.003^{* *} \\
(-2.53)\end{array}$ & $\begin{array}{c}-0.005^{* * *} \\
(-2.58)\end{array}$ & $\begin{array}{c}-0.005^{* * *} \\
(-2.63)\end{array}$ \\
\hline Education & $\begin{array}{l}0.018 \\
(1.04)\end{array}$ & $\begin{array}{l}0.018 \\
(1.03)\end{array}$ & $\begin{array}{l}0.023 \\
(0.98)\end{array}$ & $\begin{array}{l}0.023 \\
(0.98)\end{array}$ \\
\hline Compensation & $\begin{array}{l}-0.003 \\
(-0.10)\end{array}$ & $\begin{array}{l}-0.003 \\
(-0.09)\end{array}$ & $\begin{array}{l}-0.014 \\
(-0.33)\end{array}$ & $\begin{array}{l}-0.012 \\
(-0.29)\end{array}$ \\
\hline PI & $\begin{array}{l}0.272^{* * *} \\
(11.51)\end{array}$ & $\begin{array}{l}0.272^{* * *} \\
(11.51)\end{array}$ & $\begin{array}{l}0.346^{* * *} \\
(10.86)\end{array}$ & $\begin{array}{l}0.346^{* * *} \\
(10.82)\end{array}$ \\
\hline Revenue & $\begin{array}{c}0.079^{* * *} \\
(8.86)\end{array}$ & $\begin{array}{c}0.079^{* * *} \\
(8.83)\end{array}$ & $\begin{array}{c}0.105^{* * *} \\
(8.73)\end{array}$ & $\begin{array}{c}0.105^{* * *} \\
(8.71)\end{array}$ \\
\hline Establish & $\begin{array}{c}0.008^{* * *} \\
(3.75)\end{array}$ & $\begin{array}{c}0.009^{* * *} \\
(3.78)\end{array}$ & $\begin{array}{c}0.011^{* * *} \\
(3.61)\end{array}$ & $\begin{array}{c}0.011^{* * *} \\
(3.68)\end{array}$ \\
\hline DTA & $\begin{array}{l}0.000 \\
(0.02)\end{array}$ & $\begin{array}{l}-0.000 \\
(-0.01)\end{array}$ & $\begin{array}{l}-0.000 \\
(-0.16)\end{array}$ & $\begin{array}{l}-0.000 \\
(-0.18)\end{array}$ \\
\hline Profit & $\begin{array}{c}0.159^{* * *} \\
(8.52)\end{array}$ & $\begin{array}{c}0.159^{* * *} \\
(8.51)\end{array}$ & $\begin{array}{l}0.219^{* * *} \\
(8.65)\end{array}$ & $\begin{array}{c}0.218^{* * *} \\
(8.63)\end{array}$ \\
\hline Staff number & $\begin{array}{l}0.406^{* * *} \\
(15.39)\end{array}$ & $\begin{array}{l}0.405^{* * *} \\
(15.34)\end{array}$ & $\begin{array}{l}0.537^{* * *} \\
(14.92)\end{array}$ & $\begin{array}{l}0.535^{* * *} \\
(14.87)\end{array}$ \\
\hline Industry & Yes & Yes & Yes & Yes \\
\hline Region & Yes & Yes & Yes & Yes \\
\hline Year & Yes & Yes & Yes & Yes \\
\hline $\mathrm{R}^{2}$ & 0.343 & 0.344 & & \\
\hline Pseudo $\mathrm{R}^{2}$ & & & 0.153 & 0.153 \\
\hline $\mathrm{N}$ & 6158 & 6158 & 6158 & 6158 \\
\hline
\end{tabular}

This table reports both OLS and OP regression results on the role of party organization embedding and regional legal environment in the relation of private entrepreneurs of communist party members and CSR. Party organization embedding (Party) variable is an indicator that equals one if the private enterprise establishes the party organization and zero otherwise. The regional legal environment (Legal) is measured as the legal environment index in the region where the private enterprise is located, which is obtained from Wang et al. (2018). Other variables are as defined in Table 1 . T-statistics are given in parentheses. ${ }^{* *}$, ${ }^{*}$, and * indicate significance at the $1 \%, 5 \%$, and $10 \%$ level, respectively. 
There are some managerial implications for Chinese private enterprises and government departments. It is necessary for private enterprises to strengthen the construction of party organizations and increase the proportion of party member managers in the management team, which has a positive effect on improving corporate social responsibility. The government departments should create a good external legal environment for the operation of private enterprises. In particular, China is in an important period of transformation and upgrading, the government should integrate an excellent communist culture in corporate governance to strengthen the corporate social responsibility. In short, the performance of corporate social responsibility is improved through the fusion of formal legal systems and informal cultural ideologies.

\section{Funding}

This work is supported by Innovation Program for Graduate Students in Shanxi Province [grant number 2019BY023] and the Fund for Shanxi "1331 Project" Key Innovative Research Team [TD201710].

\section{Conflicts of Interest}

The authors declare no conflicts of interest regarding the publication of this paper.

\section{References}

Aguinis, H., \& Glavas, A. (2012). What We Know and Don't Know about Corporate Social Responsibility: A Review and Research Agenda. Journal of Management, 38, 932-968. https://doi.org/10.1177/0149206311436079

Chen, G. W., Hu, H. H., \& Chen, L. (2017). Do Industrial Associations Improve Corporate Social Performance: Evidence from China's Private Enterprises Survey. Journal of Public Management, 14, 102-117, 158.

Chen, L., \& Chen, H. L. (2014) The Clan Involvement, the Socio-Emotional Wealth and the Corporate Charitable Contributions: A Case Study Based on the Survey of the Private Enterprises All over China. Management World, No. 8, 90-101, 188.

Cronqvist, H., \& Yu, F. (2017). Shaped by Their Daughters: Executives, Female Socialization, and Corporate Social Responsibility. Journal of Financial Economics, 126, 543-562. https://doi.org/10.1016/j.jfineco.2017.09.003

Dai, Y. Y., Yu, W., Ning, B., \& Pan, Y. (2017). Chairman's Communist Party Member Status and Financial Violations of Private Enterprises. Accounting Research, No. 6, 75-81.

Davidson, R. H., Dey, A., \& Smith, A. J. (2018). CEO Materialism and Corporate Social Responsibility. The Accounting Review, 94, 101-126.

https://doi.org/10.2308/accr-52079

Di Giuli, A., \& Kostovetsky, L. (2014). Are Red or Blue Companies More Likely to Go Green? Politics and Corporate Social Responsibility. Journal of Financial Economics, 111, 158-180. https://doi.org/10.1016/j.jfineco.2013.10.002

Galbraith, S., \& Stephenson, H. B. (1993). Decision Rules Used by Male and Female Business Students in Making Ethical Value Judgments: Another Look. Journal of Busi- 
ness Ethics, 12, 227-233. https://doi.org/10.1007/BF01686450

Gao, Y. Q., He, X. B., \& Li, L. L. (2011). Business Owners' Social Status, Economic Achievement and Corporate Philanthropy. Economic Research Journal, 46, 111-123.

Hainmueller, J. (2012). Entropy Balancing for Causal Effects: A Multivariate Reweighting Method to Produce Balanced Samples in Observational Studies. Political Analysis, 20, 25-46. https://doi.org/10.1093/pan/mpr025

Hambrick, D. C., \& Mason, P. A. (1984). Upper Echelons: The Organization as a Reflection of Its Top Managers. Academy of Management Review, 9, 193-206.

https://doi.org/10.5465/amr.1984.4277628

Hegde, S. P., \& Mishra, D. R. (2019). Married CEOs and Corporate Social Responsibility. Journal of Corporate Finance, 58, 226-246. https://doi.org/10.1016/j.jcorpfin.2019.05.003

Hillman, A. J., \& Dalziel, T. (2003). Boards of Directors and Firm Performance: Integrating Agency and Resource Dependence Perspectives. Academy of Management Review, 28, 383-396. https://doi.org/10.5465/amr.2003.10196729

Hutton, I., Jiang, D., \& Kumar, A. (2014). Corporate Policies of Republican Managers. Journal of Financial and Quantitative Analysis, 49, 1279-1310. https://doi.org/10.1017/S0022109014000702

Liang, J., Chen, S. Y., \& Gai, Q. E. (2010). Political Participation, Governance Structure and Charitable Donation of Private Enterprises. Management World, No. 7, 109-118.

Liao, Z., Dong, J., Weng, C., \& Shen, C. (2019). CEOs' Religious Beliefs and the Environmental Innovation of Private Enterprises: The Moderating Role of Political Ties. Corporate Social Responsibility and Environmental Management, 26, 972-980. https://doi.org/10.1002/csr.1737

Manner, M. H. (2010). The Impact of CEO Characteristics on Corporate Social Performance. Journal of Business Ethics, 93, 53-72. https://doi.org/10.1007/s10551-010-0626-7

McCarthy, S., Oliver, B., \& Song, S. (2017). Corporate Social Responsibility and CEO Confidence. Journal of Banking \& Finance, 75, 280-291. https://doi.org/10.1016/j.jbankfin.2016.11.024

Muttakin, M. B., Khan, A., \& Mihret, D. G. (2018). The Effect of Board Capital and CEO Power on Corporate Social Responsibility Disclosures. Journal of Business Ethics, 150, 41-56. https://doi.org/10.1007/s10551-016-3105-y

Oh, W., Chang, Y. K., \& Cheng, Z. (2016). When CEO Career Horizon Problems Matter for Corporate Social Responsibility: The Moderating Roles of Industry-Level Discretion and Blockholder Ownership. Journal of Business Ethics, 133, 279-291. https://doi.org/10.1007/s10551-014-2397-Z

Petrenko, O. V., Aime, F., Ridge, J., \& Hill, A. (2016). Corporate Social Responsibility or CEO Narcissism? CSR Motivations and Organizational Performance. Strategic Management Journal, 37, 262-279. https://doi.org/10.1002/smj.2348

Tang, Y., Qian, C., Chen, G., \& Shen, R. (2015). How CEO Hubris Affects Corporate Social (Ir)Responsibility. Strategic Management Journal, 36, 1338-1357.

https://doi.org/10.1002/smj.2286

Wang, J., \& Coffey, B. S. (1992). Board Composition and Corporate Philanthropy. Journal of Business Ethics, 11, 771-778. https://doi.org/10.1007/BF00872309

Wang, X. L., Fan, G., \& Zhu, H. P. (2018). Marketization Index of China's Provinces: NERI Report. Beijing: Social Sciences Academic Press (China).

Xu, G. W., Li, J. Q., \& Liu, X. (2019). The Effect of the Party Organization Embedding on 
Private Enterprises Social Responsibility Investment: An Analysis Using by Private Enterprise Survey Data. Soft Science, 33, 26-31, 38.

Xu, X. X., \& Li, Y. Q. (2018). Management Gender, Institutional Environment and CSR Decisions of Enterprises. Science Research Management, 39, 80-89.

Yamamura, E., Tsutsui, Y., \& Managi, S. (2019). Male Pupils Taught by Female Homeroom Teachers Show Higher Preference for Corporate Social Responsibility in Adulthood. Journal of the Japanese and International Economies, 54, 101048. https://doi.org/10.1016/j.jjie.2019.101048

Yuan, Y., Tian, G., Lu, L. Y., \& Yu, Y. (2019). CEO Ability and Corporate Social Responsibility. Journal of Business Ethics, 157, 391-411.

https://doi.org/10.1007/s10551-017-3622-3

Zhang, Z. Y., \& Ji, L. (2013). Entrepreneurs' Demographic Characteristics and the Social Responsibility Information Disclosure. China Population, Resources and Environment, 23, 131-138.

Zhu, B. (2015). The Self-Centred Philanthropist: Family Involvement and Corporate Social Responsibility in Private Enterprises. Sociological Studies, 30, 74-97, 243. 